Омельницкая Анастасия, магистрант Инновационный Евразийский университет

г. Павлодар, Казахстан

E-mail: omel_93@mail.ru

ORCID ID: 0000-0002-5231-0671

\title{
КУЛЬТИВИРУЕМЫЙ ГРИБ ВЕШЕНКА ОБЫКНОВЕННАЯ И ИСПОЛЬЗОВАНИЕ ЕГО В МЯСНЫХ ПОЛУФАБРИКАТАХ
}

Omelnitskaya Anastassia, Master's Degree student Innovative Eurasian University

E-mail: omel_93@mail.ru ORCID ID: 0000-0002-5231-0671

\section{CULTIVATED MUSHROOM OYSTER MUSHROOM AND ITS USE IN PROCESSED MEAT.}

\begin{abstract}
Annotation: This article highlights and describes a number of valuable nutritional properties, therapeutic properties and ease of growing a cultured oyster mushroom. The purpose of the article is to analyze the study and approbation of the cultivation technology of the cultivated Oyster mushroom. Based on laboratory experiments carried out on a grown mushroom, formulations of semi-finished meat with its use have been developed.
\end{abstract}

Keywords: mushroom, Oyster mushroom, semifinished, technology and recipe.

Аннотация: В данной статье выделяются и описываются ряд иенных пищевых качеств, лечебных свойств и простота выращивания культивируемого гриба Вешенки обыкновенной. Целью статьи является анализ изучения и апробачия технологии выращивания культивируемого гриба Вешенки обыкновенной. На основании проведенных лабораторных опытов, над выращенным грибом, разработаны рецептуры мясных полуфабрикатов с его использованием.

Ключевые слова: гриб, Вешенка обыкновенная, полуфабрикат, технология, рецептура.

Казахстан славится горами и безграничными просторами степей, где можно найти очень много видов съедобных грибов. В горах сезоном считается весна, а степях их можно найти как весной, так и осенью. В нашей стране при сборе грибов, чаще всего встречаются съедобные грибы таких видов как: вешенка, синеножка, гриб подберезовик, белый степной гриб, шампиньон желтокожий, гриб - зонтик полевой, майский гриб, масленок.

Род Вешенки (Pleurotus) объединяет около 30 видов. Почти десяток видов Вешенок культивируется. Один из этих видов выращиваемых в Казахстане, мы решили изучить более подробно. Наибольшее распространение получила Вешенка обыкновенная - Pleurots ostreatus. В природе она встречается на влажных стволах деревьев лиственных пород, пнях. Данный гриб плодоносит с июня и до осенних заморозков. Он имеет белую мякоть с приятным запахом. Шляпка имеет диаметр до 20 см, гладкая, полукруглая, сероватожелтого или буроватого цвета. Пластинки, нисходящие по ножке, белые, толстые, редкие, с перемычками около ножки. Споровый порошок белый или слегка розоватый. Споры эллипсоидные. Ножка эксцентрическая, редко центральная, короткая, до 4 см длины и 2 см толщины, сужающаяся к основанию, в основном волосистая.

Грибы рода Вешенка обыкновенная обладают рядом ценных качеств и преимуществ перед другими культивируемыми грибами. Вешенка очень технологична,

Сельскохозяйственные науки - грибы 
имеет высокую скорость роста и конкурентоспособна по отношению к посторонней микрофлоре. Изучаемый нами гриб растет на различных целлюлозо- и лигнинсодержащих растительных отходах сельского хозяйства, пищевой и лесоперерабатывающей промышленности. Вообще по количеству субстратов, на которых ее культивируют, Вешенка не имеет себе равных. Самым обычным субстратом при интенсивном культивировании для нее является пшеничная солома. В странах юга Европы и США для этих целей используют кукурузные кочерыжки и стебли, в Азии - рисовую солому и отходы производства хлопка. $\mathrm{B}$ странах $\mathrm{c}$ развитой деревоперерабатывающей промышленностью при приготовлении субстрата используют до 50\% коры и опилок. В Японии Вешенка растет на лузге подсолнечника, в Индии - на бытовых отходах бумаги , в Филиппинах - на скорлупе кокосов. В качестве субстрата используют также смеси соломы, сои, костры льна, кофе, табака и винограда, картофельной кожуры, отходов переработки какао-бобов, сахарного тростника. В зависимости от выбранного субстрата при одинаковых условиях культивирования выход свежих плодовых тел Вешенки в расчете на воздушно-сухую массу субстрата будет различным. Так, солома озимой пшеницы обеспечивает выход 66,6\% свежих плодовых тел, стержни кукурузных початков - 46,7; хлопковые отходы - 68,4; смесь хлопковых отходов с соломой в соотношении 4 к 1 - 75,8\%. Приведенные цифры могут изменяться в зависимости от условий культивирования и качества используемых штаммов гриба. Технология выращивания Вешенки достаточно проста и не требует длительной подготовки субстрата. По окончании сбора грибов, субстрат можно использовать для корма животным и как отличное органическое удобрение. Так же грибы Вешенка обыкновенная применяют и в лечении. Полезные свойства этих грибов позволяют снижать содержание холестерина. Сок Вешенки обыкновенной мешает развиваться кишечной палочке. А благодаря прорастанию на деревьях они накапливают бета-глюкан, который усиливает защитную систему человека. Так же немаловажным полезным свойством является понижение процента сахара в крови. Рассматриваемый нами род гриба, содержит биологические элементы, которые выводят радионуклиды из человеческого организма. А также они помогают нормализовать давление. Данный гриб уже давно заинтересовал ученых. Они выяснили, что этот микроорганизм помогает предотвратить развитие таких болезней как: атеросклероз, гепатит, язва желудка, холецистит.

Вешенка обыкновенная содержит углеводов и жиров больше, чем в овощных культурах. В них есть витамины: D2, E и C, B, которые делают этот продукт похожим на мясо. Также в продукте содержится витамин РР. При его употреблении человеческий организм получает ферменты, которые расщепляют гликогены и жиры. Мякоть грибов содержит кальций, йод, калий и железо, биотин, тиамин.

Вешенки помогают бороться с опухолями и препятствуют дальнейшему их распространению. Ученым удалось выделить, а после запатентовать из противоопухолевые препараты, полученные из этих организмов. Подобные лекарства не являются токсичными. Рекомендуется обязательное употребление в пищу после окончания курса химиотерапии. Несомненные полезные свойства Вешенок - низкая калорийность, поэтому продукт так популярен у людей, которые решили сесть на диету. Людям болеющим бронхитом, врачи рекомендуют употреблять Вешенку обыкновенную в пищу.

Недостатком Вешенки обыкновенной является их плохая транспортабельность изза хрупкости плодовых тел. Споры Вешенки, попадая в легкие, могут вызвать аллергию. Кроме того, Вешенка подвержена вирусным заболеваниям.

Сельскохозяйственные науки - грибы
Материалы Международной практической интернет-конференции «Актуальные Проблемы Науки» 
Кроме всего вышеперечисленного, к достоинствам Вешенки можно отнести простоту кулинарной обработки.

Нами была изучена и апробирована технология выращивания культивируемого гриба Вешенка обыкновенная. В нашем случае субстратом для роста гриба выбран сухой пень карагач. Данный гриб для внесения в мясные полуфабрикаты, был обработан различными технологическими приемами: жарка, варка, высушивание, замораживание. Проведя лабораторные опыты, установлено, что выращенный нами гриб соответствует стандартным показателям и его можно использовать в приготовлении полуфабрикатов.

Разработаны рецептуры мясных полуфабрикатов:

1. Пельмени с добавлением сушеной Вешенки обыкновенной в виде порошка;

2. Голубцы с добавлением сырых (замороженных) и сушеных в виде порошка грибов Вешенка обыкновенная;

3. Котлеты, тефтели, фрикадельки с добавлением жареных, вареных, сушеных в виде порошка грибов Вешенка обыкновенная;

4. Манты с добавлением сырой (мороженой) и сушеной в виде порошка Вешенки обыкновенной;

5. Блины с добавлением вареных, жареных грибов Вешенка обыкновенная.

На основании составления рецептурных композиций были получены мясные полуфабрикаты, которые мы изучили по органолептическим, физико-химическим и микробиологическим показателям, и пришли к выводу, что данную мясную продукцию можно использовать в питании, так как она полностью соответствует всем запланированным показателям качества.

\section{ЛИТЕРАТУРА}

1. Морозов А.И. Выращивание вешенки. / М.: ООО "Издательство АСТ"; Донецк: "Сталкер", 2003. - 46 с.

2. Федоров Ф.В. Грибы. Издание шестое. / Чебоксары. Чувашское книжное издательство. 1994. $143 \mathrm{c}$.

3. Вишневский М. Все о грибах.// Энциклопедия / изд. Проспект. 2018. 688 с.

4. Богданова Н.Е. Домашняя грибная ферма. // Вешенка, шампиньон, шиитаке. / Издательство "АСТ: "Книжкин Дом"; Москва, 2015. 150 с. 